Pak. j. sci. ind. res. Ser. B: biol. sci. 201558 (2) 92-97

\title{
Accumulation of Heavy Metals in Edible Organs of Different Meat Products Available in the Markets of Lahore, Pakistan
}

\author{
Nadia Jamila, Mujtaba Baqar ${ }^{\mathrm{a}}$, Maryam Manzoor ${ }^{\mathrm{a}}$, Naeem Abbas ${ }^{\mathrm{b} *}$, Abdul Qadir ${ }^{\mathrm{a}}$, Naveed \\ Ahsan $^{\mathrm{a}}$, Irfan Ahmad Shaikh ${ }^{\mathrm{a}}$, Soniya Munir ${ }^{\mathrm{a}}$, Muhammad Arslan ${ }^{\mathrm{c}}$ and Hina Zahid ${ }^{\mathrm{a}}$ \\ ${ }^{a}$ College of Earth and Environmental Sciences, University of the Punjab, Lahore, Pakistan \\ ${ }^{\mathrm{b}} \mathrm{Centre}$ for Environment Protection Studies, PCSIR Laboratories Complex, \\ Ferozepure Road, Lahore 54600, Pakistan \\ 'Department of Earth Sciences, King Fahd University of Petroleum and Minerals (KFUPM), Dhahran, \\ Dammam, Saudi Arabia
}

(received October 2, 2014; revised March 14, 2015; accepted April 1, 2015)

\begin{abstract}
The present study assessed the accumulation of selected heavy metals $(\mathrm{Cd}, \mathrm{Cr}, \mathrm{Pb}$ and $\mathrm{Cu})$ in different organs including brain, heart, lungs, liver, stomach, kidney and flesh (muscles) of several animals commercially available in the market of Lahore, Pakistan. The concentrations found in different organs of chicken, goat and cow ranged between $0.132-2.165 \mu \mathrm{g} / \mathrm{g}$ for $\mathrm{Cd}, 0.768-2.335 \mu \mathrm{g} / \mathrm{g}$ for $\mathrm{Cr}, 0.260-1.411$ $\mu \mathrm{g} / \mathrm{g}$ for $\mathrm{Pb}$ and $0.092-1.195 \mu \mathrm{g} / \mathrm{g}$ for $\mathrm{Cu}$. In the absence of national safety standards in respect to the content of heavy metals in foodstuffs, the results obtained were compared with international guidelines and found concentrations considerably higher than the prescribed safe limits. Therefore, immediate attention must be paid to prevent public health risks associated with the presence of toxic heavy metals in the commercially available meat products.
\end{abstract}

Keywords: meat products, toxicity, heavy metals, bioaccumulation

\section{Introduction}

Meat and meat products are extensively consumed all over the world as they are substantial source of proteins, amino acids, and essential minerals, required for proper tissue formation, growth and repair (Alturiqi and Albedair, 2012; Chowdhury et al., 2011). With population increase worldwide, the consumption of the meat products has also been increased. According to Worldwatch Institute (WWI, 2014), the global meat consumption has been increased 3 fold over last four decades and by $20 \%$ only in last decade, which is significantly more than the population rise. However, in recent times, the food security is considered a significant global concern due to the direct public health risks associated with it. In this context, heavy metals contamination of food products, especially the meat products has been broadly investigated worldwide because of their direct toxic effects on human health (Asegbeloyin et al., 2012; Oforka et al., 2012; Mariam et al., 2004). It is evident that human intake is the most common source of potentially deleterious heavy metals (Bennet, 1984).

Meat contamination with heavy metals is a serious threat because of their toxicity, bioaccumulation and bio-

*Author for correspondence; E-mail: naeemchemist@gmail.com magnification in the food chain being transferred to humans (Demirezen and Uruc, 2006; Demirezen and Aksoy, 2004; Abou-Arab, 2001). These heavy metals are stored in body tissues and often have direct physiological toxic effects (Mariam et al., 2004). The accumulation of toxic heavy metals may lead to organ failure, retarded mental development, and cancer (Asegbeloyin et al., 2012). Although trace amount of heavy metals occur due to natural geological activities including such as ore formation, weathering of rocks and leaching may occur. Heavy metals are transferred to the meat's source animals via polluted water, grazing crops on irrigated sewage and industrial wastewater and contaminated feed (Sabir et al., 2003). Moreover, the contaminated soil ingested by animals, upto $18 \%$ during grazing in some domestic ungulates is also another source of these toxic elements (Thornton and Abrahams, 1983).

Since heavy metals are bio-accumulative and in less developed countries, less preference is given on existence of these toxic metals in the food products due to limited resources and lack of proper legislative framework that leads to frequent prevalence of the fatal epidemics outbreaks. The heavy metals' contamination like $\mathrm{Pb}$ can effects the animals present in its surrounding that can be risky for 
human meat consumers (Pareja-Carrera et al. 2014). Therefore, determination of heavy metals associated with the consumption of the meat products, commercially available in local markets of less developed countries has become necessary. The aim of the present study was to assess the concentration of $\mathrm{Cd}, \mathrm{Cr}, \mathrm{Cu}$ and $\mathrm{Pb}$ in different organs of chicken, mutton (goat), and beef (cow) samples, commercially available in the markets of Lahore, (Pakistan) and to evaluate the public potential health risk. These results were compared with different available international safety standards, since no national food safety standards have been formulated to date for comparison.

\section{Materials and Methods}

Sample collection. A total of 30 fresh samples of different organs (brain, heart, lungs, liver, gizzard, kidney and muscle tissues) of chicken, goat and cow were collected from June to September in 2013. Age of these animals was 3-4 months, 2-3 years and 3-4 years old for chicken, goat and cow, respectively. For sampling five markets of Lahore city, including Tollinton Market, Icchra Market, Mozang Bazar, Gulberg Main Market, and Township Main Market were visited. All samples were collected in polyethylene bags, sealed, stored in ice box and transported to the laboratory and wet digestions were performed on the same day.

Sample preparation. The samples were prepared for heavy metals determination in the laboratory using a wet digestion method. One gram of chicken, meat and beef samples was dried in oven at $105^{\circ} \mathrm{C}$ for $1 \mathrm{~h}$. The digestion was then carried out using $5 \mathrm{~mL}$ of conc. $\mathrm{HNO}_{3}$ and $1 \mathrm{~mL}$ of $\mathrm{HClO}_{4}$ in a digestion flask. The flask was then heated at $200-250{ }^{\circ} \mathrm{C}$ on a hot plate untill the digest became colourless and volume was raised up to $50 \mathrm{~mL}$. The digest was then filtered through Whattman Filter Paper No. 42, preserved in polyethylene bottles to avoid contamination and stored at $4{ }^{\circ} \mathrm{C}$ until analysis.

Standards preparation. Six working standards of 0.2 , $0.5,1,1.5,2$, and 5 ppm for $\mathrm{Cd}, \mathrm{Cr}, \mathrm{Pb}$, and $\mathrm{Cu}$ were prepared using stock solutions of $1000 \mathrm{ppm}$, prepared in accordance to the ASTM Standards. Stock solutions (1000 ppm) of selected metals were prepared by dissolving appropriate amounts of $\mathrm{Cd}\left(\mathrm{NO}_{3}\right)_{2}, \mathrm{~K}_{2} \mathrm{Cr}_{2} \mathrm{O}_{7}, \mathrm{~Pb}\left(\mathrm{NO}_{3}\right)_{2}$ and $\mathrm{CuSO}_{4} .5 \mathrm{H}_{2} \mathrm{O}$ in $1000 \mathrm{~mL}$ of doubly distilled deionised water. Further dilutions were made from these stock solutions when required.

Analysis of metals. The digests were analysed for trace metal $(\mathrm{Cd}, \mathrm{Cr}, \mathrm{Cu}$, and $\mathrm{Pb})$ in chicken, mutton and beef using a Perkin Elmer Analyst 800 Atomic Absorption Spectrophotometer using air-acetylene flame. Concentrations were determined by WinLab32 software operated.

Statistical analysis. Statistical Package for Social Sciences (SPSS) 16.0 was used for the data analyses. Descriptive statistics $\bar{x} \pm \mathrm{SD}$ was of main concern. Student's t-test was applied to study the significance $(p<0.05)$ of mean values with the permissible limits of the selected heavy metal in the organs of mutton (goat), chicken and beef (cow).

\section{Results and Discussion}

Concentration of $\mathrm{Cd}, \mathrm{Cr}, \mathrm{Pb}$ and $\mathrm{Cu}$ in different organs of mutton (goat), chicken and beef (cow) are presented in Table 1. Among the selective heavy metals of the study, the highest and lowest mean concentrations were recorded for $\mathrm{Cd}$ in liver $(2.165 \mu \mathrm{g} / \mathrm{g})$ and $\mathrm{Cu}$ in brain $(0.241 \mu \mathrm{g} / \mathrm{g})$ in mutton (goat). Moreover, it was revealed that the mean heavy metals concentrations in different organs of chicken and beef (cow) samples, ranges from $0.097 \mu \mathrm{g} / \mathrm{g}(\mathrm{Cu})$ to $2.335 \mu \mathrm{g} / \mathrm{g}(\mathrm{Cr})$ and $0.092 \mu \mathrm{g} / \mathrm{g}(\mathrm{Cu})$ to $1.421 \mu \mathrm{g} / \mathrm{g}(\mathrm{Cr})$, respectively.

Cadmium (Cd). Cadmium is a non-essential, toxic element for human and food is reported to be an important source of human exposure to Cd (Baykov et al., 1996). The Agency for Toxic Substances and Disease Registry (ATSDR, 2013) reported $\mathrm{Cd}$ as seventh most toxic substance. The high dose of $\mathrm{Cd}$ may lead to kidney dysfunction, liver and testicles damage, hypertension, lung damage and hepatic injury (John and Jeanne, 1994). Among different organs of mutton, chicken and beef samples, the highest mean concentration was recorded in kidney of mutton $(2.165 \pm 0.070 \mu \mathrm{g} / \mathrm{g})$ and lowest in heart of chicken $(0.132 \pm 0.088 \mu \mathrm{g} / \mathrm{g})$ (Table 1$)$. The concentration of $\mathrm{Cd}$ in the samples showed significant variability $(\mathrm{p}<0.05)$ among the brain, liver, gizzard, kidney and flesh of mutton; and lungs, liver, kidney and flesh of beef. This indicates the high $\mathrm{Cd}$ exposure risk associated with their consumption. It has no statistical significance in the meat of chicken ( $p>0.05)$. Cadmium mean concentration in all the chicken organs was found to be within the permissible limit of $0.5 \mathrm{ppm}$ set by FAO/WHO (2000). However, the mean concentrations in brain, liver, kidney, gizzard, and flesh samples of goat, and lungs, liver, kidney and flesh samples of cow exceeded this limit, indicating high risk associated with their consumption. Compared with other studies, the $\mathrm{Cd}$ concentrations in beef were found lower than in some previously reported studies (Abd EI-Salam et al., 
Table 1. Mean concentration $\pm \mathrm{SD}(\mu \mathrm{g} / \mathrm{g})$ of the selective heavy metals in different organs of mutton $(\mathrm{goat})(\mathrm{n}=210)$, chicken $(n=210)$ and beef $($ cow $)(n=210)$ samples

\begin{tabular}{|c|c|c|c|c|c|}
\hline & $\begin{array}{l}\text { Organ } \\
(\mathrm{n}=30)\end{array}$ & $\mathrm{Cd}$ & $\mathrm{Cr}$ & $\mathrm{Pb}$ & $\mathrm{Cu}$ \\
\hline \multirow[t]{7}{*}{ Mutton } & Brain & $1.784 \pm 0.088 * *$ & $1 \pm 0.135^{* *}$ & $1.281 \pm 0.087^{*}$ & $0.241 \pm 0.071$ \\
\hline & Heart & $0.266 \pm 0.032$ & $1.053 \pm 0.275^{*}$ & $0.559 \pm 0.216$ & $0.315 \pm 0.066$ \\
\hline & Lungs & $0.341 \pm 0.100$ & $0.967 \pm 0.160^{*}$ & $0.728 \pm 0.093$ & $0.319 \pm 0.039$ \\
\hline & Liver & $2.074 \pm 0.212 * *$ & $1.029 \pm 0.149 * *$ & $1.411 \pm 0.139^{*}$ & $1.195 \pm 0.077$ \\
\hline & Gizzard & $1.023 \pm 0.162 *$ & $1.342 \pm 0.067 * *$ & $0.974 \pm 0.197$ & $0.898 \pm 0.059$ \\
\hline & Kidney & $2.165 \pm 0.070 * *$ & $0.884 \pm 0.096^{* *}$ & $0.788 \pm 0.069$ & $0.524 \pm 0.024$ \\
\hline & Flesh & $0.741 \pm 0.064 *$ & $1.148 \pm 0.260^{*}$ & $0.683 \pm 0.122$ & $0.491 \pm 0.055$ \\
\hline \multirow{7}{*}{ Chicken } & Brain & $0.337 \pm 0.070$ & $0.768 \pm 0.069 * *$ & $0.504 \pm 0.224$ & $0.154 \pm 0.179$ \\
\hline & Heart & $0.132 \pm 0.088$ & $0.769 \pm 0.143^{*}$ & $0.697 \pm 0.297$ & $0.174 \pm 0.115$ \\
\hline & Lungs & $0.137 \pm 0.191$ & $0.902 \pm 0.278^{*}$ & $0.261 \pm 0.188$ & $0.088 \pm 0.049$ \\
\hline & Liver & $0.156 \pm 0.119$ & $1.048 \pm 0.229^{*}$ & $0.705 \pm 0.072$ & $0.168 \pm 0.069$ \\
\hline & Gizzard & $0.178 \pm 0.083$ & $2.335 \pm 0.697 *$ & $0.783 \pm 0.324$ & $0.097 \pm 0.063$ \\
\hline & Kidney & $0.182 \pm 0.092$ & $1.211 \pm 0.699 *$ & $0.846 \pm 0.367$ & $0.354 \pm 0.208$ \\
\hline & Flesh & $0.211 \pm 0.149$ & $1.912 \pm 0.458^{*}$ & $0.962 \pm 0.417$ & $0.409 \pm 0.201$ \\
\hline \multirow{7}{*}{ Beef } & Brain & $0.407 \pm 0.083$ & $1.421 \pm 0.060 * *$ & $0.698 \pm 0.023$ & $0.453 \pm 0.074$ \\
\hline & Heart & $0.398 \pm 0.089$ & $1.206 \pm 0.351^{*}$ & $0.504 \pm 0.139$ & $0.354 \pm 0.106$ \\
\hline & Lungs & $0.574 \pm 0.105^{*}$ & $1.411 \pm 0.635^{*}$ & $0.688 \pm 0.059$ & $0.211 \pm 0.082$ \\
\hline & Liver & $0.619 \pm 0.060 *$ & $1.086 \pm 0.326^{*}$ & $0.634 \pm 0.185$ & $0.181 \pm 0.089$ \\
\hline & Gizzard & $0.367 \pm 0.092$ & $1.212 \pm 0.314 *$ & $0.773 \pm 0.279$ & $0.092 \pm 0.039$ \\
\hline & Kidney & $0.634 \pm 0.191^{*}$ & $1.219 \pm 0.332 *$ & $0.714 \pm 0.088$ & $0.191 \pm 0.105$ \\
\hline & Flesh & $0.597 \pm 0.140 * *$ & $0.898 \pm 0.256^{*}$ & $1.122 \pm 0.250^{*}$ & $0.125 \pm 0.060$ \\
\hline
\end{tabular}

*and ** shows statistically significant and highly significant mean values $(\mathrm{p}<0.05)$, respectively.

2013; Alturiqi and Albedair, 2012; Chowdhury et al., 2011; Asegbeloyin et al., 2010; Mariam et al., 2004), except in the study by Akan et al. (2010) which reported higher $\mathrm{Cd}$ concentration in beef than in this study. In chicken samples, $\mathrm{Cd}$ levels were reported lower than some previous studies (Abd EI-Salam et al., 2013; Alturiqi and Albedair, 2012; Chowdhury et al., 2011; Mariam et al., 2004) but were higher than those reported by Mohammed et al. (2013) and Akan et al. (2010). However, the Cd levels detected in mutton were found higher than those previously reported (Table 2). Therefore, consumption of local meat with these high $\mathrm{Cd}$ content may cause serious public health concerns such as kidney dysfunction, liver and testicles damage, hypertension, lung damage and hepatic injury in the consumers (Maurice et al., 1994). Moreover, Cd accumulates in the liver and kidney where it interacts with essential minerals such as $\mathrm{Zn}, \mathrm{Cu}, \mathrm{Fe}$, and Se and competes for binding sites (McLaughlin et al., 1999) and also affects the calcium and phosphorus metabolism in human (Jarup et al., 1998).

Chromium (Cr). Chromium (VI) has been ranked as 17th most toxic substance (ATSDR, 2013) and has been classified into the group A: "Human Carcinogen" by USEPA (1999), due to its carcinogenic impacts. The mean concentration of $\mathrm{Cr}$ (VI) determined in different organs of mutton, chicken and beef were ranged from $0.768 \pm 0.069 \mu \mathrm{g} / \mathrm{g}$ in brain samples of chicken to 2.335 $\pm 0.697 \mu \mathrm{g} / \mathrm{g}$ in gizzard samples of chicken (Table 1). The concentration of $\mathrm{Cr}$ was statistically significant $(p<0.05)$ in all the organs of mutton, chicken and beef, particularly a high significance was reported in beef samples.

The mean $\mathrm{Cr}$ concentrations in all the studied organs of chicken, mutton, and beef samples exceeded the permissible limit of $0.1 \mathrm{ppm}$ set by ANZFA (2008). These high concentrations of $\mathrm{Cr}$ (VI) in meat samples are probably due to its uncontrolled release from industrial discharges; where it has been used in leather tanning, mining, cement and construction industries, electroplating, dyeing, paints and pigments, rust inhibitors, fungicides, alloys manufacturing and glass manufacturing industries (Fahim et al., 2006). Moreover, fascinatingly, Mahmud et al. (2011) reported a fact that in Pakistan to meet the high chicken consumption demand, the poultry chicken is fed with the feed containing small leather pieces from leather tanneries, contaminated with $\mathrm{Cr}$ (VI) during chrome tanning process. In the present study, the $\mathrm{Cr}$ concentrations in the meat products were higher as compared to previous 
studies (Abd EI-Salam et al., 2013; Chowdhury et al., 2011; Mahmud et al., 2011), except for beef samples in comparison with previously reported data by Abd EI-Salam et al. (2013) (Table 2).

Lead $(\mathbf{P b})$. Lead concentrations assessed in different organs of mutton, chicken and beef varied from lowest in lungs samples of chicken (i.e. $0.261 \pm 0.188 \mu \mathrm{g} / \mathrm{g}$ ) and highest in liver samples of mutton (i.e. $1.411 \pm$ $0.139 \mu \mathrm{g} / \mathrm{g}$ ) (Table 1). On comparison with permissible limit of 1 ppm set by ANZFA (2008), it was revealed that the mean $\mathrm{Pb}$ concentration in brain and liver samples of mutton and flesh samples of beef exceeded the limit, indicating the potential risk to human from the second most hazardous substance worldwide (ATSDR, 2013). In comparison with previously reported data, the $\mathrm{Pb}$ concentrations in this study were lower than previous reported data (Abd EI-Salam et al., 2013; Alturiqi and Albedair, 2012; Chowdhury et al., 2011; Mariam et al., 2004), and higher than those reported by Akan et al. (2010). However, results were comparable with data reported by Asegbeloyin et al. (2010). The $\mathrm{Pb}$ exposure to the meat consumer in the less developed country may impart toxic impacts on haemopoietic, nervous, renal and gastrointestinal systems (Baykov et al., 1996).

Copper ( $\mathbf{C u})$. Copper is an essential element in trace amount for the production of heamoglobin and haemocyanin in the vertebrates. It also plays a vital role in bone formation, integrity of the connective tissues, and skeletal mineralisation (Akan et al., 2010). However, its concentration in excess to the permissible limits may cause adverse impacts such as liver and kidney damage (Brito et al., 1990). Macrae et al. (1993) reported that dizziness, intestinal discomfort and headaches, hepatitis or cirrhosis, and/or hemolytic crisis in human were associated with ingestion of copper in food. The highest $\mathrm{Cu}$ level in this study was determined in liver samples of mutton $(1.195 \pm 0.077 \mu \mathrm{g} / \mathrm{g})$, while the lowest mean $\mathrm{Cu}$ concentration was recorded in lungs tissues of chicken samples $(0.088 \pm 0.049 \mu \mathrm{g} / \mathrm{g})$ (Table 1). As Cu is an essential nutrient, a recommended dietary allowance (RDA) of $0.9 \mathrm{mg} /$ day $(0.013 \mathrm{mg} / \mathrm{kg} /$ day $)$ has been set by ATSDR (2004). Thus, the Cu content in all the meat samples were in excess to recommended nutrient requirements by human through diet. Moreover, the $\mathrm{Cu}$ concentration in all the studied organs of the mutton, chicken and beef was found to be well within the permissible limits of 200 ppm set by ANZFA (2008). The copper concentrations were also found lower than those reported previously in other publications
Table 2. Concentrations (ppm) of heavy metals in meat samples reported in other studies

\begin{tabular}{|c|c|c|c|c|}
\hline $\begin{array}{l}\text { Meat } \\
\text { sample }\end{array}$ & Metal & Concentration & Region & Reference \\
\hline \multirow[t]{3}{*}{ Chicken } & $\mathrm{Cd}$ & $1.36-1.68$ & \multirow[t]{6}{*}{ Saudi Arabia } & Alturiqi \& \\
\hline & $\mathrm{Pb}$ & $7.61-10.49$ & & Albedair (2012) \\
\hline & $\mathrm{Cu}$ & $2.31-7.88$ & & \\
\hline \multirow[t]{3}{*}{ Beef } & $\mathrm{Cd}$ & $1.56-2.02$ & & \\
\hline & $\mathrm{Pb}$ & $5.85-7.93$ & & \\
\hline & $\mathrm{Cu}$ & $9.59-13.10$ & & \\
\hline \multirow[t]{2}{*}{ Chicken } & $\mathrm{Cd}$ & $0.03-0.019$ & \multirow[t]{2}{*}{ Nigeria } & \multirow{2}{*}{$\begin{array}{l}\text { Mohammed et al. } \\
\text { (2013) }\end{array}$} \\
\hline & $\mathrm{Pb}$ & 0 & & \\
\hline Beef & $\mathrm{Cu}$ & $25-30$ & Azad & Sabir et al. (2003) \\
\hline Mutton & $\mathrm{Cu}$ & $68-71$ & Kashmir, & \\
\hline Chicken & $\mathrm{Cu}$ & $11-13$ & Pakistan & \\
\hline \multirow[t]{3}{*}{ Beef } & $\mathrm{Cd}$ & $0.17-0.22$ & \multirow[t]{9}{*}{ Nigeria } & \multirow[t]{9}{*}{ Akan et al. (2010) } \\
\hline & $\mathrm{Pb}$ & $0.15-0.25$ & & \\
\hline & $\mathrm{Cu}$ & $0.54-0.87$ & & \\
\hline \multirow[t]{3}{*}{ Mutton } & $\mathrm{Cd}$ & $0.34-0.76$ & & \\
\hline & $\mathrm{Pb}$ & $0.08-0.16$ & & \\
\hline & $\mathrm{Cu}$ & $0.34-0.98$ & & \\
\hline \multirow[t]{3}{*}{ Chicken } & $\mathrm{Cd}$ & $0.16-0.27$ & & \\
\hline & $\mathrm{Pb}$ & $0.16-0.22$ & & \\
\hline & $\mathrm{Cu}$ & $0.01-1.44$ & & \\
\hline \multirow[t]{3}{*}{ Beef } & $\mathrm{Cd}$ & 0.33-0.909 & \multirow{9}{*}{$\begin{array}{l}\text { Lahore, } \\
\text { Pakistan }\end{array}$} & \multirow{9}{*}{$\begin{array}{l}\text { Mariam et al. } \\
\text { (2004) }\end{array}$} \\
\hline & $\mathrm{Pb}$ & $2.02-2.19$ & & \\
\hline & $\mathrm{Cu}$ & $5.42-93.24$ & & \\
\hline \multirow[t]{3}{*}{ Mutton } & $\mathrm{Cd}$ & $0.37-0.45$ & & \\
\hline & $\mathrm{Pb}$ & $3.85-4.25$ & & \\
\hline & $\mathrm{Cu}$ & $5.01-318.82$ & & \\
\hline \multirow[t]{3}{*}{ Chicken } & $\mathrm{Cd}$ & $0.31-0.49$ & & \\
\hline & $\mathrm{Pb}$ & $3.1-3.15$ & & \\
\hline & $\mathrm{Cu}$ & $6.91-12.86$ & & \\
\hline \multirow[t]{4}{*}{ Beef } & $\mathrm{Cd}$ & $0.03-8.04$ & Bangladesh & Chowdhury et al. \\
\hline & $\mathrm{Cr}$ & $0.06-1.22$ & & $(2011)$ \\
\hline & $\mathrm{Pb}$ & $0.67-24.9$ & & \\
\hline & $\mathrm{Cu}$ & $0.15-11.51$ & & \\
\hline Goat & $\mathrm{Cd}$ & 0.15 & & \\
\hline & $\mathrm{Cr}$ & 0.08 & & \\
\hline & $\mathrm{Pb}$ & 1.35 & & \\
\hline & $\mathrm{Cu}$ & 3.92 & & \\
\hline Chicken & $\mathrm{Cd}$ & 5.20 & & \\
\hline & $\mathrm{Cr}$ & 0.69 & & \\
\hline & $\mathrm{Pb}$ & 41.94 & & \\
\hline & $\mathrm{Cu}$ & 10.33 & & \\
\hline Beef & $\mathrm{Cd}$ & $0.28-1.50$ & Nigeria & Asegbeloyin et al. \\
\hline & $\mathrm{Pb}$ & $0.80-1.42$ & & $(2010)$ \\
\hline Mutton & $\mathrm{Cd}$ & $0.04-0.93$ & & \\
\hline & $\mathrm{Pb}$ & $0.02-1.36$ & & \\
\hline Beef & $\mathrm{Cd}$ & $0.3-1.23$ & Kohat, & Abd EI-Salam et al. \\
\hline & $\mathrm{Cr}$ & $0.3-15.76$ & Pakistan & (2013) \\
\hline & $\mathrm{Pb}$ & $2.5-11.83$ & & \\
\hline & $\mathrm{Cu}$ & $4.6-8.58$ & & \\
\hline Goat & $\mathrm{Cd}$ & $0.37-1.58$ & & \\
\hline & $\mathrm{Cr}$ & $0.41-0.46$ & & \\
\hline & $\mathrm{Pb}$ & $1.85-2.7$ & & \\
\hline & $\mathrm{Cu}$ & $3.22-82.83$ & & \\
\hline Chicken & $\mathrm{Cd}$ & $0.86-1.51$ & & \\
\hline & $\mathrm{Cr}$ & $0.07-0.53$ & & \\
\hline & $\mathrm{Pb}$ & $1.95-3.25$ & & \\
\hline & $\mathrm{Cu}$ & $0.41-20.86$ & & \\
\hline Chicken & $\mathrm{Cr}$ & $0.233-1.266$ & $\begin{array}{l}\text { Lahore, } \\
\text { Pakistan }\end{array}$ & $\begin{array}{l}\text { Mahmud et al. } \\
\text { (2011) }\end{array}$ \\
\hline
\end{tabular}


(Abd EI-Salam et al., 2013; Alturiqi and Albedair, 2012; Chowdhury et al., 2011; Mariam et al., 2004; Sabir et al., 2003) (Table 2). Therefore, $\mathrm{Cu}$ contents in the local meat samples could be considered with insignificant risk to public.

\section{Conclusion}

This study revealed that the concentrations of $\mathrm{Cd}, \mathrm{Cr}$ and $\mathrm{Pb}$ in different organs of meat (chicken, goat and cow) samples, commercially available in local markets of Lahore, (Pakistan) exceed to the permissible limits set by international health organizations. The high concentrations of non-essential metals have identified the high risk vulnerability of the local population on consumption of the contaminated meat products. Therefore, this study suggests a critical need to formulate and implement national food safety standards in Pakistan to ensure the availability of safe meat products in Pakistan. Further studies are needed to investigate the risk associated with bioaccumulation of these trace metals in locals due to consumption of the contaminated meat products.

\section{References}

Abd EI-Salam, N.M., Ahmad, S., Basir, A., Rais, A.K., Bibi, A., Ullah, R., Shad, A.A., Muhammad, Z., Hussain, I. 2013. Distribution of heavy metals in the liver, kidney, heart, pancreas and meat of cow, buffalo, goat, sheep and chicken from Kohat market, Pakistan. Life Science Journal, 10: 937-940.

Abou-Arab, A.A.K. 2001. Heavy metal contents in Egyptian meat and the role of detergent washing on their levels. Food and Chemical Toxicology, 39: 593-599.

Akan, J.C., Abdulrahman, F.I., Sodipo, O.A., Chiroma, Y.A. 2010. Distribution of heavy metals in the liver, kidney and meat of beef, mutton, caprine and chicken from Kasuwan Shanu Market in Maiduguri Metropolis, Borno State, Nigeria. Research Journal of Applied Sciences, Engineering and Technology, 2: 743-748.

Alturiqi, A.S., Albedair, L.A. 2012. Evaluation of some heavy metals in certain fish, meat and meat products in Saudi Arabian markets. The Egyptian Journal of Aquatic Research, 38: 45-49.

ANZFA, 2008. (Australia New Zealand Food Authority). Retrieved from: http://www.foodstandards.gov.au/ Asegbeloyin, J.N., Onyimonyi, A.E., Ujam, O.T., Ukwueze, N.N., Ukoha, P.O. 2012. Assessment of toxic trace metals in selected fish species and parts of domestic animals. Pakistan Journal of Nutrition, 9: 213-215.

ATSDR, 2013. Summary Data for 2013 Priority List of Hazardous Substances. pp. 1, Agency for Toxic Substances and Disease Registry Division of Toxicology and Human Health Sciences, Atlanta, Georgia, USA. http://www.atsdr.cde.gov/spl/ resources/ATSDR, 2013-SPL- Detailed_Data-Table pdf.

ATSDR, 2004. Toxicological Profile for Copper. pp. 12. U.S. Department of Health and Services. Public Health Service. Agency for Toxic Substances and Disease Registry Division of Toxicology and Human Health Sciences, Atlanta, Georgia, USA. http://www.atsdr.cdc.gov/toxprofiles/tp132.pdf.

Baykov, B.D., Stoyanov, M.P., Gugova, M.L. 1996. Cadmium and lead bioaccumulation in male chickens for high food concentrations. Toxicological \& Environmental Chemistry, 54: 155-159.

Bennet, F.G. 1984. Modeling Exposure Routes of Trace Metals from Sources to Animal and Human Health. pp. 345-356, Springer Verlag, Berlin, Germany.

Brito, G., Díaz, C., Galindo, L., Hardisson, A., Santiago, D., García-Montelongo, M.F. 1990. Levels of metals in canned meat products: Intermetallic correlations. Bulletin of Environmental Contamination and Toxicology, 44: 309-316.

Chowdhury, M.Z.A., Siddique, Z.A., Hossain, S.M.A., Kazi, A.I., Ahsan, A.A., Ahmed, S., Zaman, M.M. 2011. Determination of essential and toxic metals in meats, meat products and eggs by spectrophotometric method. Journal of the Bangladesh Chemical Society, 24: $165-172$.

Demirezen, O., Uruc, K. 2006. Comparative study of trace elements in certain fish, meat and meat products. Meat Science, 74: 255-260.

Demirezen, D., Aksoy, A. 2004. Accumulation of heavy metals in Typha angustifolia (L.) and Potamogeton pectinatus (L.) living in Sultan Marsh (Kayseri, Turkey). Chemosphere, 56: 685-696.

Fahim, N.F., Barsoum, B.N., Eid, A.E., Khalil, M.S.2006. Removal of chromium (III) from tannery wastewater using activated carbon from sugar industrial waste. Journal of Hazardous Materials, 136: 303-309.

FAO/WHO. 2000. Joint FAO/WHO Expert Committee on Food Additives, 32nd Meeting. Toxicological evaluation of certain veterinary drug residues in food. WHO Food Additives Series, 23. 
Jarup, L., Berglund, M., Elinder, C.G., Nordberg, G.1998. Health effects of cadmium exposure -a review of the literature. Scandinavian Journal of Work, Environment \& Health, 24: 1-51.

John, H.H., Jeanne, I.R. 1994. Food additives, contaminants and natural toxins. In: Modern Nutrition in Health and Disease, Maurice E.S., A.O. James, S.L. Moshe and Febiger, (eds.), pp. 1597-1598, $8^{\text {th }}$ edition, Part II.

Macrae, R., Robinson, R.K., Sadler, M.J. 1993. Encyclopaedia of Food Science, Food Technology and Nutrition. Academic Press, London, UK. 6: 40654069.

Mahmud, T., Rehman, R., Ali, S., Anwar, J., Abbas, A., Farooq, M., Ali, A.2011. Estimation of chromium (VI) in various body parts of local chicken. Journal of the Chemical Society of Pakistan, 33: 339-342.

Mariam, I., Iqbal, S., Nagra, S.A. 2004. Distribution of some trace and macrominerals in beef, mutton and poultry. International Journal of Agriculture and Biology, 6: 816-820.

Maurice, E.S., James, A.O., Moshe, S. 1994. Modern Nutrition in Health and Disease. pp. 59-75. $8^{\text {th }}$ edition, vol. 1, Lea \& Febiger, Baltimore, PA, USA.

McLaughlin, M.J., Parker, D.R., Clarke, J.M. 1999. Metals and micronutrients - Food safety issues. Field Crops Research, 60: 143-163.

Mohammed, A.I., Kolo, B., Geidam, Y.A. 2013. Heavy metals in selected tissues of adult chicken layers (Gallus spp). ARPN Journal of Science and Technology, 3: 518-522.

Oforka, N.C., Osuji, L.C., Onwuachu, U.I. 2012. Assessment of heavy metal pollution in muscles and internal organs of chickens raised in Rivers State, Nigeria. Journal of Emerging Trends in Engineering and Applied Sciences, 3: 406-411.

Pareja-Carrera, J., Mateo, R., Rodríguez, Estivae, J. 2014. Lead $(\mathrm{Pb})$ in sheep exposed to mining pollution: Implications for animal and human health. Ecotoxicology and Environmental Safety, 108: 210-216.

Sabir, S.M., Khan, S.W., Hayat, I. 2003. Effect of environmental pollution on quality of meat in District Bagh, Azad Kashmir. Pakistan Journal of Nutrition, 2: 98-101.

Thornton, I., Abrahams, P. 1983. Soil ingestion - a major pathway of heavy metals into livestock grazing contaminated land. Science of the Total Environment, 28: $287-294$.

USEPA, 1999. Integrated Risk Information System (IRIS) on Chromium VI. U.S. Environmental Protection Agency, National Center for Environmental Assessment, Office of Research and Development, Washington, DC, USA.

WWI, 2014. Global meat production and consumption continue to rise. [online] http://www. worldwatch. org/global-meat-production-and-consumptioncontinue-rise (Accessed 12 June 2014). 